\title{
Genetic and epigenetic changes of genes on chromosome 3 in human urogenital tumors
}

\author{
V. V. Gordiyuk \\ Institute of Molecular Biology and Genetics NAS of Ukraine \\ 150, Akademika Zabolotnogo Str., Kyiv, Ukraine, 03680 \\ vasilij_gordiyuk@yahoo.com
}

\begin{abstract}
Numerous disorders of genes and alterations of their expression are observed on a short arm of human chromosome 3, particularly in 3p14, 3p21, 3p24 compact regions in epithelial tumors. These aberrations affect the key biological processes specific for cancerogenesis. Such genes or their products could be used for diagnostics and prognosis of cancer. Genetical and epigenetical changes of a number of genes on chromosome 3 in human urogenital cancer, their role in cellular processes and signal pathways and perspectives as molecular markers of cancer diseases are analyzed in the review.
\end{abstract}

Keywords: human chromosome 3, tumor suppressor genes, DNA methylation, microRNA, urogenital cancer, molecular oncomarker.

The process of malignization is promoted by genetic and epigenetic changes, affecting different chromosomes to a certain degree. Numerous chromosome aberrations (for instance, loss of heterozygosity) as well as decrease in the expression of many genes due to hypermethylation of promoters, histone modifications, alternative splicing of transcripts or disorders of protein translation by microRNA are observed on the short arm of human chromosome 3 in cells of tumors of epithelial origin.

Deletions on arm $3 p$ are related to the most frequent changes in the majority of tumors of epithelial origin. These aberrations were observed in $90-100 \%$ of cases of renal clear cell carcinoma (RCC) and cervical carcinoma (CC), and were significantly present in ovarian cancer (OC) and prostate cancer (PC) $[1,2]$. Amplifications of genes of chromosome 3 play an important role in malignization of urogenital organs [3]. Satellite DNA and retrotransposons condition the presence of duplications on the short arm of human

(C) Institute of Molecular Biology and Genetics NAS of Ukraine, 2011 chromosome 3, promoting carcinogenesis [4]. Monosomy and polyploidia of chromosome 3 also promote the development of urogenital malignant neoplasms, for instance, CC [5].

Epigenetic and genetic disorders in the regulation of the level of expression of some genes of human chromosome 3 in tumor cells will be discussed later, in the analysis of aberrations of its specific region.

"Topography" of genes on chromosome 3 and cancer. The highest number of genes of human chromosome 3 , susceptible to changes in urogenital tumors, is located in the compact regions $3 \mathrm{p} 14,3 \mathrm{p} 21$, and $3 \mathrm{p} 24$.

Thus, there is evident considerable percentage of deletions in locus 3p14.1-3p14.2 [6] and decrease in expression in RCC for fragile histidine triad gene (FHIT), 3p14.2 [7]. Hetero- and homozygous deletions of FHIT gene may result in disorders in the processes of DNA replication in cells [8]. The development of renal carcinoma (RC) is also related to the translocations of microphthalamia-associated transcription factor 
(MITF) gene, 3p14.2-p14.1 [9]. OC is characterized by the loss of heterozygosity in the region 3p14 [10] and hypermethylation of FHIT [11]. The decrease in the expression of genes FHIT and ADAMTS9 (ADAM metallopeptidase with thrombospondin type motif 9 , $3 \mathrm{p} 14.1)$ increases the risk of $\mathrm{PC}[12,13]$. The decrease in the expression of FOXP1 (forkhead box P1, 3p14.1) [14] and specific deletion, resulting in the formation of chimeric gene [15], are also observed in this oncopathology. At the early stages of CC there were observed deletions [16], hypermethylation and loss of expression some genes in locus 3p14.2 [17]. The results of research with NotI-microarray show methylation/ deletions of genes FOXP1 and MITF in this region in urogenital tumors $[18,19]$.

Inactivation of the cluster of about 20 potential genes - suppressors of tumor growth of region $3 \mathrm{p} 21.3$, affects the course of key biological processes, determining the specificity of carcinogenesis [20], therefore, these genes may be used as biomarkers for diagnostics and prognosis of oncological diseases [21].

The methylation of promoters of genes RASSF1A (Ras association domain family member 1, 3p21.3) [22] and $L T F$ (lactotransferrin, 3p21.3) [23] is revealed in PC. The methylation of RASSF1A [24] and TU3A (3p21.1) [25] as well as high percentage of deletions in the region $3 \mathrm{p} 21.3$, in particular, for gene NPRL2 (nitrogen permease regulator-like 2) were found in RC [26]. This oncopathology is also characterized by the loss of heterozygosity and hypermethylation of gene MLH1 (mutL homolog 1, colon cancer, nonpolyposis type 2, 3p21.3) [27, 28]. The effect of aberrations of telomeric $3 \mathrm{p} 21.3 \mathrm{~T}$ and centromeric $3 \mathrm{p} 21.3 \mathrm{C}$ regions, for instance, deletions of gene DLEC1 (deleted in lung and esophageal cancer 1, 3p21.3), is observed in CC [29]. This disease is related to hypermethylation of genes BLU (3p21.3), RASSF1A [30] and deletions in NPRL2 [26]. The development of OC is promoted by hypermethylation of the $\mathrm{CpG}$ regions of genes $\mathrm{MLH1}$ [31] and DLEC1. The decrease of DLEC1 expression is also connected with hypoacetylation of histones [32].The decrease in expression of genes RIS1 (Ras induced senescence 1,3p21.3) and HEG1 (3p21.2) [33] as well as hypermethylation of promoter of gene RASSF1A [34] were demonstrated for serous ovarian cancer. A considerable decrease in expression of
HYAL1 (hyaluronoglucosaminidase 1, 3p21.3) and, therefore, anomalous accumulation of hyaluronan, tumorigenic polysaccharide, in extracellular matrix [35] were also observed at this pathology.

The data, obtained with of NotI-microarrays, demonstrate genetic/epigenetic changes in cancer of urogenital organs in the $3 \mathrm{p} 21.3$ region for genes ITGA9 (integrin, alpha 9), RBSP3 (RB protein serine phosphatase gene on chromosome 3) and GNAI2 (guanine nucleotide binding protein, alpha inhibiting activity polypeptide 2) [18, 19].

Considerable disorders were observed in the 3 p24 region of chromosome 3 in urogenital tumors. For instance, the loss of heterozygosity was observed in locus 3p24.2 in RC [36], deletions were found in CC [37] and OC [10], point mutations and loss of heterozygosity of THRB (thyroid hormone receptor, beta, 3p24.2) - in PC [38]. The increase in expression of one of antiapoptotic gene IL-17RL forms (interleukin-17 receptor-like protein, 3p25.3-3p24) due to alternative splicing was also observed for this pathology [39]. In PC the deletions in loci 3p24 and 3 p22 are found in more than half of patients [40]. The results of NotI-microarray demonstrate methylation/ deletions in urogenital tumors in the $3 \mathrm{p} 24$ region for genes RPL15 (ribosomal protein L15), RARbeta (retinoic acid receptor, beta), $L R R C 3 B$ (leucine rich repeat containing 3B), SH3BP5 (SH3-domain binding protein 5), and THRB [18, 19].

Urogenital malignant neoplasms are known for aberrations in the region $3 \mathrm{p} 25-3 \mathrm{p} 26$. For instance, the loss of heterozygosity was revealed in $\mathrm{CC}$ in loci $3 p 26.1-3 p 25.2$ [41]. Deletions 3p25-3p26 were found in OC [10] and RC [42]. Some authors revealed the connection between disorders in locus 3p25-3p26 and the risk of developing PC [43]. The data of NotI-microarray demonstrate changes in the region 3 p25-26 in cancer of urogenital sphere for genes BHLHB2 (basic helix-loop-helix domain containing, class B, 2), WNT7A (wingless-type MMTV integration site family, member 7A), VHL (von Hippel-Lindau tumor suppressor), and MINT24 [18, 19].

Besides, the gene of histone deacetylase HDAC11 with the locus $\mathrm{CpG}$ in promoter site was localized in the 3 p25 region [44]. This enzyme regulates the expression of interleukin-10 and thus - the processes of 
inflammation and immune response [45]. Inactivation of HDAC11 in cancer may testify to its tumor-suppressing features.

Genetic aberrations on the long $\mathrm{q}$ arm of human chromosome 3 are significantly present in $\mathrm{CC}$ and are most frequent in the $3 \mathrm{q} 21$ region [46]. The increase in expression of gene EVII (ecotropic viral integration site 1,3q26), destroying normal duplication of centrosomes, is also related to the risk of $\mathrm{CC}$ development. The product of this gene interacts with histone methyl-transferases, promoting immortalization of tumor cells [47]. $100 \%$ of investigated samples of invasive $\mathrm{CC}$ show amplifications of TERC (telomerase RNA component, $3 \mathrm{q} 26$ ), which is also required for immortalization [48].

A compact region is revealed inside the $3 \mathrm{q} 21$ region, containing potential tumor-suppressing genes and oncogenes, associated with OC and RC [20]. Gene PIK3CA (phosphoinositide-3 kinase, catalytic alpha polypeptide, 3q26) is amplified in OC [49]. $\mathrm{PC}$ is characterized by amplifications of genes IL12A (interleukin 12A, 3q25-3q26), SOX2 (SRY (sex determining region Y)-box 2, 3q26-q27), MDS1 (myelodysplasia syndrome 1, 3q25-3q27) [50], and TLOC1 (translocation protein 1, 3q26.2) [51].

The results of NotI-microarray[s] demonstrate the disorders in q arm of human chromosome 3 in cancer of urogenital organs for genes GATA2 (GATA binding protein 2), $R A P 2 B$ (member of RAS oncogene family), FGF12 (fibroblast growth factor 12), TRH (thyrotropin-releasing hormone) and SOX2 [18, 19].

Therefore, the relation to tumor formation in urogenital sphere was first revealed for some genes of human chromosome 3 and confirmed for others using the research with NotI-microarrays. In particular, these data were obtained for gene GNAI2, the decrease in expression of which was previously revealed in OC [52], for $R A R B$, hypermethylated and capable of losing heterozygosity in CC [53, 54], for RBSP3, which is susceptible to deletions in this pathology and decreases the expression [55]. The data of inactivation due to hypermethylation of promoter or mutations in RCC [56] also coincide with the data of NotI-microarray for gene $V H L$.

MicroRNAs, the genes of which are localized on chromosome 3 , deserve special attention. It is noteworthy that disbalance in expression of microRNA in cancer, including urogenital organs, may be conditioned by both genetic and epigenetic mechanisms [57]. The progression of prostate cancer is related to the decrease on the level of miR26a (3p22.2), which is a regulator of immune response and apoptosis [58]. The expression of miR135a (3p21.1) also changes in PC [59]. In RCC there is a sharp drop in the expression of miR135a and miR-28 (3q28) [60]. Changes in gene mir-191 (3p21.31) are associated with OC [61]. The disorder of expression of miR-191, miR-28, miR-425 (3p21.31) and let-7g (3p21.1) is remarkable for CC [62]. Similarly to the protein-coding genes, suppressors of tumor growth, the genes of microRNA tend to cluster in specific regions of chromosomes [63].

The largest number of microRNA genes of human chromosome 3 , the changes in expression of which were revealed in urological tumors, is concentrated in the 3 p21 region. This region is the subject to deletions, in RCC, in particular [60].

Functions and participation in signaling of gene products of chromosome 3 . The specificities of changes in a number of genes of human chromosome 3 and proteins, coded by them in urogenital malignant neoplasms, are presented in Table. According to the literature data, genetic/epigenetic aberrations or disorders in expression of definite genes were found only in urogenital malignant tumors. However, the changes in many genes are associated with different tumors of epithelial origin as well as with malignant neoplasms of other nosological types. These genes either belong to known/potential tumor suppressors or are oncogenes. Proteins, coded by them, participate in the regulation of cellular cycle, cell differentiation and apoptosis. They are presented by transcription factors, growth factors/cytokines, receptor proteins, and enzymes.

Some genes of human chromosome 3 demonstrate opposite features in different types of malignant neoplasms. For instance, as stated above, the decrease in expression is remarkable for transcription factor FOXP1 in epithelial tumors. On the contrary, in lymphoma FOXP1 acts as an oncogene due to translocations [64].

The identification of signaling pathways, their key elements and corresponding aberrations in tumor 
Ways of inactivating genes of human chromosome 3 in malignant neoplasms and functions of proteins, coded by them

\begin{tabular}{|c|c|c|c|c|}
\hline Gene & Regulation/change in expression & Tumor localization & Functions of protein, cellular processes & Reference \\
\hline MINT24 & Methylation/deletions & $\begin{array}{l}\text { Kidneys, ovaries, cervix uteri, large } \\
\text { intestines }\end{array}$ & Unknown & {$[18],[19]$} \\
\hline BHLHB2 & Methylation/deletions & $\begin{array}{l}\text { Cervix uteri, ovaries, pancreatic } \\
\text { gland }\end{array}$ & $\begin{array}{l}\text { Transcription factor, cell } \\
\text { differentiation, apoptosis }\end{array}$ & {$[18],[19]$} \\
\hline$I T G A 9$ & Methylation/deletions & Cervix uteri, ovaries, lungs & Glycoprotein, adhesion & {$[18],[19]$} \\
\hline NKIRAS1 & Methylation/deletions & Cervix uteri, skin, stomach & Apoptosis & {$[18]$} \\
\hline RARbeta & Methylation/deletions & $\begin{array}{l}\text { Kidneys, cervix uteri, ovaries, } \\
\text { esophagus, liver, leukemia }\end{array}$ & Cell differentiation, apoptosis & {$[18],[19]$} \\
\hline RBSP3 & Methylation/deletions & Kidneys, cervix uteri, ovaries, lungs & $\begin{array}{l}\text { Phosphatase, regulation of cellular } \\
\text { cycle }\end{array}$ & {$[18],[19]$} \\
\hline$V H L$ & $\begin{array}{l}\text { Methylation/deletions, } \\
\text { mutations }\end{array}$ & $\begin{array}{l}\text { Kidneys, cervix uteri, ovaries, } \\
\text { mammary gland, pancreatic gland, } \\
\text { leukemia }\end{array}$ & $\begin{array}{l}\text { Ubiquitinylation, apoptosis, } \\
\text { angiogenesis }\end{array}$ & {$[18],[19]$} \\
\hline WNT7A & Methylation/deletions & $\begin{array}{l}\text { Cervix uteri, lungs, pancreatic gland, } \\
\text { neuroblastoma }\end{array}$ & $\begin{array}{l}\text { Signaling protein, embryogenesis, } \\
\text { adhesion, cell differentiation }\end{array}$ & {$[18]$} \\
\hline$F O X P 1$ & Methylation/deletions & $\begin{array}{l}\text { Kidneys, ovaries, cervix uteri, } \\
\text { prostate, rectum, lymphoma }\end{array}$ & Transcription factor, ontogenesis & $\begin{array}{l}{[14],[15],} \\
{[18]}\end{array}$ \\
\hline$L R R C 3 B$ & Methylation/deletions & $\begin{array}{l}\text { Kidneys, ovaries, cervix uteri, } \\
\text { stomach and large intestine, } \\
\text { leukemia }\end{array}$ & DNA reparation, cell proliferation & {$[18],[19]$} \\
\hline$G A T A 2$ & Methylation/deletions & Ovaries, prostate gland, leukemia & $\begin{array}{l}\text { Transcription factor, } \\
\text { hematopoiesis }\end{array}$ & {$[19]$} \\
\hline$F G F 12$ & $\begin{array}{l}\text { Change in expression, } \\
\text { methylation/deletions }\end{array}$ & Nasopharynx/thyroid gland, ovaries & $\begin{array}{l}\text { Factor of growth of fibroblasts, } \\
\text { angiogenesis }\end{array}$ & [19] \\
\hline$R A P 2 B$ & $\begin{array}{l}\text { Increase in expression, } \\
\text { methylation/deletions }\end{array}$ & Lungs/ovaries & Small GTPhase & {$[19]$} \\
\hline MITF & $\begin{array}{l}\text { Translocations, } \\
\text { methylation/deletions }\end{array}$ & Melanoma, kidneys, ovaries & $\begin{array}{l}\text { Transcription factor, cell } \\
\text { differentiation }\end{array}$ & {$[9],[19]$} \\
\hline$T R H$ & $\begin{array}{l}\text { Increase in expression, } \\
\text { methylation/deletions }\end{array}$ & Melanoma/ovaries & Autocrine growth factor & [19] \\
\hline SOX2 & Methylation/deletions & $\begin{array}{l}\text { Ovaries, prostate gland, lungs, } \\
\text { stomach, glia }\end{array}$ & $\begin{array}{l}\text { Transcription factor, cell cycle, } \\
\text { apoptosis }\end{array}$ & {$[19]$} \\
\hline THRB & $\begin{array}{l}\text { Methylation/deletions, } \\
\text { mutations }\end{array}$ & $\begin{array}{l}\text { Neuroblastoma, thyroid gland, liver, } \\
\text { kidneys, ovaries }\end{array}$ & Receptor of thyroid hormone & {$[19],[38]$} \\
\hline GNAI2 & $\begin{array}{l}\text { Methylation/deletions, } \\
\text { decrease in expression }\end{array}$ & Kidneys, ovaries & Receptor protein $\mathrm{G}$ & [19] \\
\hline SH3BP5 & $\begin{array}{l}\text { Methylation/deletions, } \\
\text { decrease in expression }\end{array}$ & Cervix uteri, mammary gland & $\begin{array}{l}\text { Signaling protein, growth and } \\
\text { differentiation }\end{array}$ & {$[18]$} \\
\hline$M L H 1$ & $\begin{array}{l}\text { Gene methylation and } \\
\text { dimethylation of histone } \\
\text { H3 }\end{array}$ & $\begin{array}{l}\text { Gastrointestinal tract, prostate, } \\
\text { ovaries }\end{array}$ & Apoptosis & {$[27],[28]$} \\
\hline
\end{tabular}




\begin{tabular}{|c|c|c|c|c|}
\hline Gene & Regulation/change in expression & Tumor localization & Functions of protein, cellular processes & Reference \\
\hline$N P R L 2$ & Deletions & Kidneys, cervix uteri, lungs & Proliferation & [26] \\
\hline ADAMTS9 & $\begin{array}{l}\text { Methylation, decrease in } \\
\text { expression }\end{array}$ & Nasopharynx, prostate gland & Adhesion & {$[13]$} \\
\hline HIAL1 & Decrease in expression & Ovaries & Enzyme & {$[35]$} \\
\hline TERC & Amplification & Cervix uteri & Immortalization & [48] \\
\hline EVII & $\begin{array}{l}\text { Amplification; increase in } \\
\text { expression }\end{array}$ & $\begin{array}{l}\text { Prostate gland; cervix uteri, } \\
\text { leukemia }\end{array}$ & Remodeling of chromatin & {$[47]$} \\
\hline TLOC1 & $\begin{array}{l}\text { Amplification; increase in } \\
\text { expression }\end{array}$ & Prostate gland & Ubiquitinylation & {$[51]$} \\
\hline$I L 12 A$ & Amplification & Cervix uteri; prostate gland & Cytokine & {$[50]$} \\
\hline$P I 3 K C A$ & Amplification & Ovaries & Kinase, proliferation & [49] \\
\hline
\end{tabular}

formation is extremely important for understanding carcinogenesis in general and the development of specific types of cancer. Many products of genes of chromosome 3 , the relation of which to cancer of urogenital sphere is well-known, either are components of signaling cascades or affect their functioning.

A classic example of this fact is kinase PIK3CA. Via signaling pathway PIK3/Akt an estrogen regulates the expression of HIF 1alpha, the key factor of invasion and metastasis, which was shown for OC, in particular [65]. The role of $V H L$ in inhibition of expression of HIF1alpha is known [66]. According to the recent data, tumor-suppressing microRNA, coded by genes of chromosome 3, e.g. miR135a, participate in the regulation of response to hypoxia in RCC [60].

The products of genes VHL and NKIRAS1 regulate in different ways the activity of signaling cascade with the participation of NF-kappa B, which realizes its anti-apoptotic features in transformed cells, when activated with protein Ras [67]. Parallel inactivation of $V H L$ and RASSF1A was revealed in RCC, which may testify to synergism of activity of these tumor-suppressing genes [68]. It is known that RASSF 1A participates in the regulation of signaling pathways together with Erk [69].

The signaling pathway WNT7A/catenin beta is required for cell adhesion [70]. Besides, via activation of JNK-pathway WNT7A induces the expression of cadherins and cell differentiation. In its turn, the product of gene $S H 3 B P 5$, protein sab, regulating the level of expression of BTK (Bruton tyrosine kinase) and probably playing the role of a switch between JNKand BTK-signaling pathways in mitochondria, is a target for JNK and SAPK3 [71].

Protein RBSP3 promotes the functioning of signaling pathway of retinoblastoma due to dephosphorylation of RB1 [72]. Protein SOX2, a structurally important component of Golgi apparatus, which is likely to induce apoptosis with caspase 3 and GRASP65, participates in the regulation of this pathway too [73].

Oncogene BRAF regulates the transcription of MITF via ERK and accelerates degradation of MITF by ubiquitin-proteosome pathway [74]. The product of LTF gene participates in the regulation of MAPK and promotes the termination of cellular cycle [75].

Protein FHIT serves as a target for protein-kinase Src, modulating the signaling pathway Akt-survinin [76]. On the other hand, the product of gene NPRL2 is a negative regulator of signaling pathway Src/PDK1 (3phosphoinositide-dependent protein kinase-1), required for proliferation [77]. Protein FOXP1, a target for androgen and its receptor in PC, participates in the signaling pathways of hormone-dependent tumors [78].

Cytokine IL-12 causes the induction of interferon gamma, participates in differentiation of Th1 and Th2, and activates transcription factor STAT4 [79]. 
MicroRNA let-7g is involved in the signaling cascade, affecting the capability of tumors to metastasis [80]. Oncogene myc is capable of inhibiting the expression of miR26a in cancer and, therefore, controlling the level of interferon beta [81].

It is noteworthy that signaling pathways, involved in the development of a tumor of the same organ, may change depending on histological specificities, as it was shown for different subtypes of OC [82].

A more detailed analysis of participation of products of genes, discussed in the review, in the signaling pathways of cells with the consideration of known complicated interactions, which vary in different types of cancer, is well beyond the frame of current work. Nevertheless, it is evident that human chromosome 3 is an important object for study of carcinogenic processes as well as for determination of genes - tumor suppressors and potential oncomarkers of cancer diseases, including malignant neoplasms of urogenital sphere.

Chromosome 3 and molecular oncomarkers. At present there is an active search for molecular oncomarkers, including epigenetic ones, which may be used for prediction of tumor behavior, for instance, probability of metastasis and resistance to medical preparations as well as for timely diagnostics.

The possibility of early diagnostics and prognosis of the disease course is investigated for urogenital malignant neoplasms. Epigenetic regulation of a number of genes is a frequent cause of decreased resistance to medicine for cancer, $\mathrm{OC}$ in particular [83].

At early stages of $\mathrm{CC}$ the monosomy and polyploidy of chromosome 3 can be potential oncomarkers [5]. This pathology has evident hypermethylation and loss of heterozygosity in tumor suppressors of chromosome 3 - VHL, FHIT, RARB, RASSF 1A. The decrease in the expression of RASSF $1 A$ was considered as prognostic factor due to the mentioned aberrations [54].

Besides, the degree of methylation of promoter RASSF 1A correlates with the progression of RCC [24]. The aggression of RC [84] and PC depends on the level of TERC expression. The increase in TERC expression in prostate cancer corresponds to the increase in the degree of differentiation by Gleason and the level of PSA (Prostate Specific Antigen) in blood serum of patients [85]. The expression profile of microRNA is also suggested for diagnostic and prognostic purposes in $\mathrm{PC}$, in particular, for evaluation of probability of relapse after prostatectomy [86].

The methylation of promoter of gene $M L H 1$ results in sharp increase in OC progression [87]. Hypermethylation of GC-rich clusters of ribosomal genes is also revealed for this oncopathology [88]. Poor survival for OC is related to the amplification of gene EVII [89].

Despite the fact that the methylation of CpG-loci is remarkable for carcinogenesis in general, the picture of methylation is specific for each type of tumors [90]. Besides, it may change within one localization depending on the clinical stage of disease (for instance, the degree of methylation of promoter RASSF $1 A$ increases with progression of RCC) [68] and on the histological subtype of the tumor (for instance, changes in the methylation status of genes in serous, mucinous and clear cell renal carcinoma are different) [91]. The profile of gene expression also changes with tumor progression. The sets (signatures) of genes with aberrant expression in cancer are unique for each histological subtype within one type of tumors. On the contrary, similar signatures are alike for different malignant neoplasms with close histological structure, which is notable for RCC and clear cell OC [92]. This specificity should be considered while analyzing the sets of corresponding markers.

As the profiles of expression of microRNAs were also found to be specific for different histological subtypes within one localization, it was suggested to use the panels of microRNAs, in particular, for molecular classification of renal tumors [93].

In clinical conditions a possibility of revealing molecular oncomarkers in biological liquids of the organism is extremely important, as it simplifies the diagnostic process significantly. The latter is absolutely true regarding malignant neoplasms of urogenital organs.

Gene $A C P P$ (prostatic acid phosphatase, $3 q 21-3 q 23)$ codes a protein, the amount of which in blood of patients with PC increases considerably compared to hyperplasia [94]. It was also shown that in case of PC the level of microRNA in blood serum may serve as a marker of response to chemotherapy [95]. It 
is suggested to conduct early diagnostics of PC by determining aberrant methylation of promoters of genes in the patients' samples, taken for Papanicolaou test [96].

In case of OC, blood samples reveal changes in the methylation of gene RASSF1A on stage I with the specificity of $100 \%$ and sensitivity of $82 \%$ [33]. The profile of microRNAs, determined in the patients' blood, is also used for OC screening [97].

It should be noted that hypermethylation of RASSF $1 A$ gene in RC, PC, and CC may be an important indicator for early tumor detection in blood serum or urine [22]. The analysis of methylation profile of DNA, related to the surface of blood cells, e.g. RARbeta 2 fragments, seems to be promising for early diagnostics of cancer [98].

The research of genetic and epigenetic (cancer specific epigenetic fingerprint) specificities in each definite case of malignant neoplasms using novel technologies reveals new perspectives for clinical diagnostics of early stages of oncological diseases, evaluation of their possible development and cancer therapy. The implementation of large-scale international projects, including Human Epigenomic Project [99], will undoubtedly promote the introduction of achievements of molecular biology into medical practice.

\section{В. В. Гордиюк}

Генетические и эпигенетические изменения генов 3-й хромосомы человека в клетках опухолей урогенитальной сферы

Институт молекулярной биологии и генетики НАН Украины Ул. Академика Заболотного, 150, Киев, Украина, 03680

\section{Резюме}

На коротком плече 3-й хромосомы человека, особенно в компактных участках $3 p 14,3 p 21$ и 3p24, в клетках опухолей эпителиального происхождения наблюдается значительное количество нарушений генов и изменение их экспрессии. Эти аберрации влияют на протекание ключевых биологических проиессов, определяющих особенности канщерогенеза. Такие гены или их продукты могут быть использованы для диагностики и прогноза течения онкологических заболеваний. В обзоре проанализированы генетические и эпигенетические изменения ряда генов 3-й хромосомы человека при раке органов урогенитальной сферы, их роль в клеточных прочессах и сигнальных путях, а также перс- пективы применения в качестве молекулярных онкомаркеров.
Ключевые слова: 3-я хромосома человека, гены-супрессоры опухолей, метилирование ДНК, микроРНК, рак урогенитальной сферы, молекулярные онкомаркеры.

\section{В. В. Гордіюк}

Генетичні та епігенетичні зміни генів 3-ї хромосоми людини у клітинах пухлин урогенітальної сфери

Резюме

На короткому плечі 3-ї хромосоми людини, особливо на компактних ділянках 3p14, 3p21 i 3p24, у клітинах пухлин епітеліального походження спостерігається значна кількість порушень генів та змін їхньої експресії. Подібні аберації впливають на проходження ключових біологічних прочесів, які визначають особливості канцерогенезу. Такі гени або їхні продукти можна використовувати для діагностики і прогнозування перебігу онкологічних захворювань. В огляді проаналізовано генетичні та епігенетичні зміни низки генів 3-ї хромосоми людини при раку органів урогенітальної сфери, їхня роль у клітинних проиесах і сигнальних шляхах, а також перспективи застосування як молекулярних онкомаркерів.

Ключові слова: 3-я хромосома людини, гени - супресори пухлин, метилювання ДНК, мікроРНК, рак урогенітальної сфери, молекулярні онкомаркери.

\section{СПИСОК ЛИТЕРАТУРЫ}

1. Lubinski J., Hadaczek P., Podolski J., Toloczko A., Sikorski A., McCue P., Druck T., Huebner K. Common regions of deletion in chromosome regions $3 \mathrm{p} 12$ and $3 \mathrm{p} 14.2$ in primary clear cell renal carcinomas // Cancer Res.-1994.-54, N 14.P. 3710-3713.

2. Gordiyuk $V . V$. Genetic and epigenetic changes in malignant cells of tumors of urogenital organs // Biopolym. Cell.-2010.-26, N 6.-P. 450- 460.

3. van Gils W., Kilic E., Bruggenwirth H. T., Vaarwater J., Verbiest M. M., Beverloo B., van Til-Berg M. E., Paridaens D., Luyten G. P., de Klein A. Regional deletion and amplification on chromosome 6 in a uveal melanoma case without abnormalities on chromosomes 1p, 3 and 8 // Melanoma Res.2008.-18, N 1.-P. 10-15.

4. Darai-Ramqvist E., Sandlund A., Muller S., Klein G., Imreh $S$., Kost-Alimova M. Segmental duplications and evolutionary plasticity at tumor chromosome break-prone regions // Genome Res.-2008.-18, N 3.-P. 370-379.

5. Wang X., Zheng B., Zhang R. R., Li S., Chen X., Mulvihill J. $J$., Lu X., Pang H., Liu H. Automated analysis of fluorescent in situ hybridization (FISH) labeled genetic biomarkers in assisting cervical cancer diagnosis // Technol. Cancer Res. Treat.-2010.-9, N 3.-P. 231-242.

6. Yoshimoto T., Matsuura K., Karnan S., Tagawa H., Nakada C., Tanigawa M., Tsukamoto Y., Uchida T., Kashima K., Akizuki S., Takeuchi I., Sato F., Mimata H., Seto M., Moriyama $M$. High-resolution analysis of DNA copy number alterations and gene expression in renal clear cell carcinoma // J. Pathol.-2007.-213, N 4.-P. 392-401.

7. Hadaczek P., Podolski J., Toloczko A., Kurzawski G., Sikorski A., Rabbitts P., Huebner K., LubinskiJ. Losses at 3p common deletion sites in subtypes of kidney tumours: histopatho- 
logical correlations // Virchows Arch.-1996.-429, N 1.P. 37-42.

8. Durkin S. G., Ragland R. L., Arlt M. F., Mulle J. G., Warren S. T., Glover T. $W$. Replication stress induces tumor-like microdeletions in FHIT/FRA3B // Proc. Natl Acad. Sci. USA.2008.-105, N 1.-P. 246-251.

9. Hintzy M. C., Camparo P., Vasiliu V., Peyromaure M., Vieillefond $A$. Renal carcinoma associated with MiTF/TFE translocation: report of six cases in young adults // Prog. Urol.2008. -18, N 5.-P. 275-280.

10. Cody N. A., Ouellet V., Manderson E. N., Quinn M. C., FilaliMouhim A., Tellis P., Zietarska M., Provencher D. M., MesMasson A. M., Chevrette M., Tonin P. N. Transfer of chromosome 3 fragments suppresses tumorigenicity of an ovarian cancer cell line monoallelic for chromosome $3 \mathrm{p} / /$ Oncogene.-2007.-26, N 4.-P. 618-632.

11. Hong F. Z., Wang B., Li H. M., Liew C. T. Hypermethylation of fragile histidine triad gene and 3p14 allelic deletion in ovarian carcinomas // Zhonghua Bing Li Xue Za Zhi.-2005.34, N 5.-P. 257-261.

12. Fouts R. L., Sandusky G. E., Zhang S., Eckert G. J., Koch M. O., Ulbright T. M., Eble J. N., Cheng L. Down-regulation of fragile histidine triad expression in prostate carcinoma // Cancer.-2003.-97, N 6.-P. 1447-1452.

13. Cross N. A., Chandrasekharan S., Jokonya N., Fowles A., Hamdy F. C., Buttle D. J., Eaton C. L. The expression and regulation of ADAMTS-1, $-4,-5,-9$, and -15 , and TIMP-3 by TGFbeta1 in prostate cells: relevance to the accumulation of versican // Prostate.-2005.-63, N 3.-P. 269-275.

14. Banham A. H., Beasley N., Campo E., Fernandez P. L., Fidler C., Gatter K., Jones M., Mason D. Y., Prime J. E., Trougouboff P., Wood K., Cordell J. L. The FOXP1 winged helix transcription factor is a novel candidate tumor suppressor gene on chromosome 3p // Cancer Res.-2001.-61, N 24.- P. 8820-8829.

15. Taylor B. S., Schultz N., Hieronymus H., Gopalan A., Xiao Y., Carver B. S., Arora V. K., Kaushik P., Cerami E., Reva B., Antipin Y., Mitsiades N., Landers T., Dolgalev I., Major J. E., Wilson M., Socci N. D., Lash A. E., Heguy A., Eastham J. A., Scher H. I., Reuter V. E., Scardino P. T., Sander C., Sawyers $C$. L., Gerald $W$. L. Integrative genomic profiling of human prostate cancer // Cancer Cell.-2010.-18, N 1.-P. 11-22.

16. Kanjanavirojkul N., Limpaiboon T., Patarapadungkit N., Yuenyao P., Pairojkul C. Chromosome 3 p alterations in northeastern Thai women with cervical carcinoma // Asian. Pac. J. Cancer Prev.-2005.-6, N 4.-P. 501-504.

17. Ki K. D., Lee S. K., Tong S. Y., LeeJ. M., Song D. H., Chi S. G. Role of 5'-CpG island hypermethylation of the FHIT gene in cervical carcinoma // J. Gynecol. Oncol.-2008.-19, N 2.P. 117-122.

18. Kashuba V. I., Skripkina I. Ia., Saraev D. V., Gordiiuk V. V., Vinnitskaia A. B., Tsyba L. A., Pogrebnoi P. V., Blinov V. M., Zabarovskii E. R., Ryndich $A$. V. Identification of changes in gene loci potentially associated with cervical cancer using NotI microarrays // Ukr. Biokhim. Zhur.-2006.-78, N 2.P. 113-120.

19. Gordiyuk V. V., Gerashchenko G. V., Skrypkina I. Ya., Simonchuk O. V., Pavlova T. V., Ugrin D. D., Manzhura E. P., Vakulenko G. O., Zabarovsky E. R., Rynditch A. V., Kashuba $V$. I. Identification of chromosome 3 epigenetic and genetic abnormalities and gene expression changes in ovarian cancer // Biopolym. Cell.-2008.-24, N 4.-P. 223-332.

20. Loginov V. I., Bazov I. V., Khodyrev D. S., Pronina I. V., Kazubskaia T. P., Ermilova V. D., Gar'kavtseva R. F., Zbarov- skii E. R., Braga E. A. Human chromosome 3P regions of putative tumor-suppressor genes in renal, breast, and ovarian carcinomas // Genetika.-2008.-44, N 2.-P. 250-256.

21. Angeloni D. Molecular analysis of deletions in human chromosome 3 p21 and the role of resident cancer genes in disease // Brief. Funct. Genomic Proteomic.-2007.-6, N 1.-P. 19-39.

22. Pfeifer G. P., Dammann R. Methylation of the tumor suppressor gene RASSF1A in human tumors // Biochemistry (Mosc).-2005.-70, N 5.-P. 576-583.

23. Shaheduzzaman S., Vishwanath A., Furusato B., Cullen J., Chen Y., Bacez L., Nau M., Ravindranath L., Kim K. H., Mohammed A., Chen Y., Ehrich M., Srikantan V., Sesterhenn I. A., McLeod D., Vahey M., Petrovics G., Dobi A., Srivastava $S$. Silencing of Lactotransferrin expression by methylation in prostate cancer progression // Cancer. Biol. Ther.-2007.-6, N 7.-P. 1088-1095.

24. Loginov V. I., Khodyrev D. S., Pronina I. V., Kazubskaia T. P., Ermilova V. D., Gar'kavtseva R. F., Braga E. A. Methylation of promoter region of $R A S S F 1 A$ gene and frequencies of allelic imbalances in chromosome 3 critical regions are correlated with progression of clear cell renal cell carcinoma // Mol. Biol. (Mosk).-2009.-43, N 3.-P. 429-438.

25. Awakura Y., Nakamura E., Ito N., Kamoto T., Ogawa O. Methylation-associated silencing of TU3A in human cancers // Int. J. Oncol.-2008.-33, N 4.-P. 893-899.

26. Li J., Wang F., Haraldson K., Protopopov A., Duh F. M., Geil L., Kuzmin I., Minna J. D., Stanbridge E., Braga E., Kashuba V. I., Klein G., Lerman M. I., Zabarovsky E. R. Functional characterization of the candidate tumor suppressor gene NPRL2/G21 located in 3p21.3C // Cancer Res.-2004.-64, N 18.-P. 6438-6443.

27. Rubio-Del-Campo A., Salinas-Sanchez A. S., Sanchez-Sanchez F., Gimenez-Bachs J. M., Donate-Moreno M. J., Pastor-Navarro H., Carrion-Lypez P., Escribano J. Implications of mismatch repair genes $h M L H 1$ and $h M S H 2$ in patients with sporadic renal cell carcinoma // BJU Int.-2008.-102, N 4.P. 504-509.

28. Arai E., Ushijima S., Tsuda H., Fujimoto H., Hosoda F., Shibata T., Kondo T., Imoto I., Inazawa J., Hirohashi S., Kanai $Y$. Genetic clustering of clear cell renal cell carcinoma based on array-comparative genomic hybridization: its association with DNA methylation alteration and patient outcome // Clin. Cancer Res.-2008.-14, N 17.-P. 5531-5539.

29. Senchenko V., Liu J., Braga E., Mazurenko N., Loginov W., Seryogin Y., Bazov I., Protopopov A., Kisseljov F. L., Kashuba V., Lerman M. I., Klein G., Zabarovsky E. R. Deletion mapping using quantitative real-time PCR identifies two distinct 3 p21.3 regions affected in most cervical carcinomas // Oncogene.-2003.-22, N 19.-P. 2984-2992.

30. Lai H. C., Lin Y. W., Chang C. C., Wang H. C., Chu T. W., Yu M. H., Chu T. Y. Hypermethylation of two consecutive tumor suppressor genes, $B L U$ and $R A S S F 1 A$, located at $3 \mathrm{p} 21.3$ in cervical neoplasias // Gynecol. Oncol.-2007.-104, N 3.P. 629-635.

31. Zhang H., Zhang S., Cui J., Zhang A., Shen L., Yu. H. Expression and promoter methylation status of mismatch repair gene $h M L H 1$ and $h M S H 2$ in epithelial ovarian cancer // Aust. NZJ Obstet. Gynaecol.-2008.-48, N 5.-P. 505-509.

32. Kwong J., Lee J. Y., Wong K. K., Zhou X., Wong D. T., Lo K. W., Welch W. R., Berkowitz R. S., Mok S. C. Candidate tumorsuppressor gene $D L E C 1$ is frequently downregulated by promoter hypermethylation and histone hypoacetylation in human epithelial ovarian cancer // Neoplasia.-2006.-8, N 4.P. 268-278. 
33. Birch A. H., Quinn M. C., Filali-Mouhim A., Provencher D. M., Mes-Masson A. M., Tonin P. N. Transcriptome analysis of serous ovarian cancers identifies differentially expressed chromosome 3 genes // Mol. Carcinog.-2008.-47, N 1.P. 56-65.

34. de Caceres I., Battagli C., Esteller M., Herman J. G., Dulaimi E., Edelson M. I., Bergman C., Ehya H., Eisenberg B. L., Cairns $P$. Tumor cell-specific BRCA1 and RASSF1A hypermethylation in serum, plasma, and peritoneal fluid from ovarian cancer patients // Cancer Res.-2004.-64, N 18.-P. 64766481

35. Nykopp T. K., Rilla K., Sironen R., Tammi M. I., Tammi R. H., Hamalainen K., Heikkinen A. M., Komulainen M., Kosma V. M., Anttila M. Expression of hyaluronan synthases (HAS1-3) and hyaluronidases (HYAL1-2) in serous ovarian carcinomas: inverse correlation between HYAL1 and hyaluronan content // BMC Cancer.-2009.-12, N 9.-P. 143.

36. Salama M. E., Worsham M. J., DePeralta-Venturina M. Malignant papillary renal tumors with extensive clear cell change: a molecular analysis by microsatellite analysis and fluorescence in situ hybridization // Arch. Pathol. Lab. Med.2003.-127, N 9.-P. 1176-1181.

37. Guo Z., Wu F., Asplund A., Hu X., Mazurenko N., Kisseljov F., Ponten J., Wilander E. Analysis of intratumoral heterogeneity of chromosome $3 \mathrm{p}$ deletions and genetic evidence of polyclonal origin of cervical squamous carcinoma // Mod. Pathol.-2001.-14, N 2.-P. 54-61.

38. Muller I., Urban K., Pantel K., Schwarzenbach H. Comparison of genetic alterations detected in circulating microsatellite DNA in blood plasma samples of patients with prostate cancer and benign prostatic hyperplasia // Ann. N. Y. Acad. Sci-2006-1075 - - P. 222-229.

39. Haudenschild D. R., Curtiss S. B., Moseley T. A., Reddi A. H. Generation of interleukin-17 receptor-like protein (IL-17RL) in prostate by alternative splicing of RNA // Prostate.-2006.66, N 12.-P. 1268-1274.

40. Balachandar V., Kumar B. L., Sasikala K., Manikantan P., Sangeetha R., Devi S. M. Identification of a high frequency of chromosomal rearrangements in the centromeric regions of prostate cancer patients // J. Zhejiang Univ. Sci. B.-2007.-8, N 9.-P. 638-646.

41. Dasgupta S., Chakraborty S. B., Roy A., Roychowdhury S., Panda C. K. Differential deletions of chromosome $3 p$ are associated with the development of uterine cervical carcinoma in Indian patients // Mol. Pathol.-2003.-56, N 5.-P. 263-269.

42. Braga E., Senchenko V., Bazov I., Loginov W., Liu J., Ermilova V., Kazubskaya T., Garkavtseva R., Mazurenko N., Kisseljov F., Lerman M. I., Klein G., Kisselev L., Zabarovsky E. R. Critical tumor-suppressor gene regions on chromosome 3P in major human epithelial malignancies: allelotyping and quantitative real-time PCR // Int. J. Cancer.-2002.-100, N 5.P. 534-541.

43. Rokman A., Baffoe-Bonnie A. B., Gillanders E., Fredriksson H., Autio V., Ikonen T., Gibbs K. D., Jr., Jones M., Gildea D., Freas-Lutz D., Markey C., Matikainen M. P., Koivisto P. A., Tammela T. L., Kallioniemi O. P., Trent J., Bailey-Wilson J. $E$., Schleutker $J$. Hereditary prostate cancer in Finland: finemapping validates $3 \mathrm{p} 26$ as a major predisposition locus // Hum Genet.-2005.-116, N 1-2.-P. 43-50.

44. Voelter-Mahlknecht S., Ho A. D., Mahlknecht U. Chromosomal organization and localization of the novel class IV human histone deacetylase 11 gene // Int. J. Mol. Med.-2005.-16, N 4.-P. 589-598.
45. Villagra A., Cheng F., Wang H. W., Suarez I., Glozak M., Maurin M., Nguyen D., Wright K. L., Atadja P. W., Bhalla K., Pinilla-Ibarz J., Seto E., Sotomayor E. M. The histone deacetylase HDAC11 regulates the expression of interleukin 10 and immune tolerance // Nat. Immunol.-2009.-10, N 1.P. $92-100$.

46. Wilting S. M., de Wilde J., Meijer C. J., Berkhof J., Yi Y., van Wieringen W. N., Braakhuis B. J., Meijer G. A., Ylstra B., Snijders P. J., Steenbergen R. D. Integrated genomic and transcriptional profiling identifies chromosomal loci with altered gene expression in cervical cancer // Genes Chromosomes Cancer.-2008.-47, N 10.-P. 890-905.

47. Goyama S., Nitta E., Yoshino T., Kako S., Watanabe-Okochi N., Shimabe M., Imai Y., Takahashi K., Kurokawa M. EVI-1 interacts with histone methyltransferases SUV39H1 and G9a for transcriptional repression and bone marrow immortalization // Leukemia.-2010.-24, N 1.-P. 81-88.

48. Andersson S., Sowjanya P., Wangsa D., Hjerpe A., Johansson B., Auer G., Gravitt P. E., Larsson C., Wallin K. L., Ried T., Heselmeyer-Haddad $K$. Detection of genomic amplification of the human telomerase gene TERC, a potential marker for triage of women with HPV-positive, abnormal Pap smears // Am. J. Pathol.-2009.-175, N 5.-P. 1831-1847.

49. Woenckhaus J., Steger K., Sturm K., Kunstedt K., Franke F. E., Fenic I. Prognostic value of PIK3CA and phosphorylated AKT expression in ovarian cancer // Virchows Arch.-2007.450, N 4.-P. 387-395.

50. Sattler H. P., Lensch R., Rohde V., Zimmer E., Meese E., Bonkhoff H., Retz M., Zwergel T., Bex A., Stoeckle M., Wullich $B$. Novel amplification unit at chromosome 3q25-q27 in human prostate cancer // Prostate.-2000.-45, N 3.-P. 207215 .

51. Jung V., Kindich R., Kamradt J., Jung M., Muller M., Schulz $W$. A., Engers R., Unteregger G., Stockle M., Zimmermann R., Wullich B. Genomic and expression analysis of the 3q25-q26 amplification unit reveals TLOC1/SEC62 as a probable target gene in prostate cancer // Mol. Cancer Res.-2006.-4, N 3.P. 169-176.

52. Peters D. G., Kudla D. M., Deloia J. A., Chu T. J., Fairfull L., Edwards R. P., Ferrell R. E. Comparative gene expression analysis of ovarian carcinoma and normal ovarian epithelium by serial analysis of gene expression // Cancer Epidemiol. Biomarkers Prev.-2005.-14, N 7.-P. 1717-1723.

53. Feng Q., Balasubramanian A., Hawes S. E., Toure P., Sow $P$. S., Dem A., Dembele B., Critchlow C. W., Xi L., Lu H., McIntosh M. W., Young A. M., Kiviat N. B. Detection of hypermethylated genes in women with and without cervical neoplasia // J. Natl Cancer Inst.-2005.-97, N 4.-P. 273-282.

54. Choi C. H., Lee K. M., Choi J. J., Kim T. J., Kim W. Y., Lee J. W., Lee S. J., Lee J. H., Bae D. S., Kim B. G. Hypermethylation and loss of heterozygosity of tumor suppressor genes on chromosome $3 \mathrm{p}$ in cervical cancer // Cancer Lett.-2007.255, N 1-P. 26-33.

55. Anedchenko E. A., Kiseleva N. P., Dmitriev A. A., Kiselev F. L., Zabarovskii E. R., Senchenko V. N. Tumor suppressor gene $R B S P 3$ in cervical carcinoma: copy number and transcriptional level // Mol. Biol. (Mosk).-2007.-41, N 1.-P. 86-95.

56. Kuroki T., Trapasso F. Yendamuri S., Matsuyama A., Alder H., Mori M., Croce C. M. Allele loss and promoter hypermethylation of VHL, RAR-beta, RASSF1A, and FHIT tumor suppressor genes on chromosome $3 p$ in esophageal squamous cell carcinoma // Cancer Res.-2003.-63, N 13.-P. 3724-3728.

57. Zhang L., Volinia S., Bonome T., Calin G. A., Greshock J., Yang N., Liu C. G., Giannakakis A., Alexiou P., Hasegawa K., 
Johnstone C. N., Megraw M. S., Adams S., Lassus H., Huang J., Kaur S., Liang S., Sethupathy P., Leminen A., Simossis V. A., Sandaltzopoulos R., Naomoto Y., Katsaros D., Gimotty P. A., DeMichele A., Huang Q., Butzow R., Rustgi A. K., Weber B. L., Birrer M. J., Hatzigeorgiou A. G., Croce C. M., Coukos $G$. Genomic and epigenetic alterations deregulate microRNA expression in human epithelial ovarian cancer // Proc. Natl Acad. Sci. USA.-2008.-105, N 19.-P. 7004-7009.

58. Theodore S. C., Rhim J. S., Turner T., Yates C. MiRNA 26a expression in a novel panel of African American prostate cancer cell lines // Ethn. Dis.-2010.-20, N 1.-P. 96-100.

59. Wang G., Wang Y., Feng W., Wang X., Yang J. Y., Zhao Y., Wang $Y$., Liu $Y$. Transcription factor and microRNA regulation in androgen-dependent and -independent prostate cancer cells // BMC Genomics.-2008.-16, N 9.-P. 22.

60. Juan D., Alexe G., Antes T., Liu H., Madabhushi A., Delisi C., Ganesan S., Bhanot G., Liou L. S. Identification of a microRNA panel for clear-cell kidney cancer // Urology.-2010.75, N 4.-P. 835-841.

61. Shen J., DiCioccio R., Odunsi K., Lele S. B., Zhao H. Novel genetic variants in miR-191 gene and familial ovarian cancer // BMC Cancer.-2010.-18, N 10.-P. 47

62. Lui W. O., Pourmand N., Patterson B. K., Fire A. Patterns of known and novel small RNAs in human cervical cancer // Cancer Res.-2007.-67, N 13.-P. 6031-6043.

63. Altuvia Y., Landgraf P., Lithwick G., Elefant N., Pfeffer S., Aravin A., Brownstein M. J., Tuschl T., Margalit H. Clustering and conservation patterns of human microRNAs // Nucl. Acids Res.-2005.-33, N 8.-P. 2697-2706.

64. Goatly A., Bacon C. M., Nakamura S., Ye H., Kim I., Brown P. J., Ruskone-Fourmestraux A., Cervera P., Streubel B., Banham A. H., Du M. Q. FOXP1 abnormalities in lymphoma: translocation breakpoint mapping reveals insights into deregulated transcriptional control // Mod. Pathol.-2008.21, N 7.-P. 902-911.

65. Hua K., Din J., Cao Q., Feng W., Zhang Y., Yao L., Huang Y. Zhao $Y$., Feng $Y$. Estrogen and progestin regulate HIF-1alpha expression in ovarian cancer cell lines via the activation of Akt signaling transduction pathway // Oncol. Rep.-2009.-21, N 4.-P. 893-898.

66. Lee S., Garner E. I., Welch W. R., Berkowitz R. S., Mok S. C. Over-expression of hypoxia-inducible factor 1 alpha in ovarian clear cell carcinoma // Gynecol. Oncol.-2007.-106, N 2.-P. 311-317.

67. Fenwick C., NaS. Y., Voll R. E., Zhong H., Im S. Y., LeeJ. W., Ghosh $S$. A subclass of Ras proteins that regulate the degradation of IkappaB // Science.-2000.-287, N 5454.-P. 869-873.

68. Tokinaga K., Okuda H., Nomura A., Ashida S., Furihata M., Shuin T. Hypermethylation of the RASSF $1 A$ tumor suppressor gene in Japanese clear cell renal cell carcinoma // Oncol. Rep.-2004.-12, N 4.-P. 805-810.

69. Thaler S., Hahnel P. S., Schad A., Dammann R., Schuler M. RASSF $1 A$ mediates p21Cip1/Waf1-dependent cell cycle arrest and senescence through modulation of the Raf-MEKERK pathway and inhibition of Akt // Cancer Res.-2009.-69, N 5.-P. 1748-1757.

70. Winn R. A., Van Scoyk M., Hammond M., Rodriguez K., Crossno J. T., Jr., Heasley L. E., Nemenoff R. A. Antitumorigenic effect of Wnt 7a and Fzd 9 in non-small cell lung cancer cells is mediated through ERK-5-dependent activation of peroxisome proliferator-activated receptor gamma // J. Biol. Chem.-2006.-281, N 37.-P. 26943-26950.

71. Yamadori T., Baba Y., Matsushita M., Hashimoto S., Kurosaki M., Kurosaki T., Kishimoto T., Tsukada S. Bruton's tyrosi- ne kinase activity is negatively regulated by Sab, the Btk-SH3 domain-binding protein // Proc. Natl Acad. Sci. USA.-1999.96, N 11.-P. 6341-6346.

72. Kashuba V. I., Li J., Wang F., Senchenko V. N., Protopopov A., Malyukova A., Kutsenko A. S., Kadyrova E., Zabarovska V. I., Muravenko O. V., Zelenin A. V., Kisselev L. L., Kuzmin I., Minna J. D., Winberg G., Ernberg I., Braga E., Lerman M. I., Klein G., Zabarovsky E. R. RBSP3 (HYA22) is a tumor suppressor gene implicated in major epithelial malignancies // Proc. Natl Acad. Sci. USA.-2004.-101, N 14-P. 4906-4911.

73. Otsubo T., Akiyama Y., Yanagihara K., Yuasa Y. SOX2 is frequently downregulated in gastric cancers and inhibits cell growth through cell-cycle arrest and apoptosis // $\mathrm{Br}$. J. Cancer.-2008.-98, N 4.-P. 824-831.

74. Wellbrock C., Rana S., Paterson H., Pickersgill H., Brummelkamp T., Marais R. Oncogenic BRAF regulates melanoma proliferation through the lineage specific factor MITF // PLoS One.-2008.-3, N 7.-P. e2734.

75. Zhou Y., Zeng Z., Zhang $W$., Xiong $W$., Wu M., Tan Y., Yi W., Xiao L., Li X., Huang C., Cao L., Tang K., Li X., Shen S., Li G. Lactotransferrin: a candidate tumor suppressor-deficient expression in human nasopharyngeal carcinoma and inhibition of NPC cell proliferation by modulating the mitogen-activated protein kinase pathway // Int. J. Cancer.-2008.-123, N 9.P. 2065-2072.

76. Semba S., Trapasso F., Fabbri M., McCorkell K. A., Volinia S., Druck T., Iliopoulos D., Pekarsky Y., Ishii H., Garrison P. N., Barnes L. D., Croce C. M., Huebner K. Fhit modulation of the Akt-survivin pathway in lung cancer cells: Fhit-tyrosine 114 (Y114) is essential // Oncogene.-2006.-25, N 20.P. 2860-2872.

77. Kurata A., Katayama R., Watanabe T., Tsuruo T., Fujita N. TUSC4/NPRL2, a novel PDK1-interacting protein, inhibits PDK1 tyrosine phosphorylation and its downstream signaling // Cancer Sci.-2008.-99, N 9.-P. 1827-1834.

78. Takayama K., Horie-Inoue K., Ikeda K., Urano T., Murakami K., Hayashizaki Y., Ouchi Y., Inoue S. FOXP1 is an androgen-responsive transcription factor that negatively regulates androgen receptor signaling in prostate cancer cells // Biochem. Biophys. Res. Communs.-2008.-374, N 2.-P. 388393.

79. Chen X., Han S., Wang S., Zhou X., Zhang M., Dong J., Shi X., Qian N., Wang X., Wei Q., Shen H., Hu Z. Interactions of IL$12 \mathrm{~A}$ and IL-12B polymorphisms on the risk of cervical cancer in Chinese women // Clin. Cancer Res.-2009.-15, N 1.P. 400-405.

80. Dangi-Garimella S., Yun J., Eves E. M., Newman M., Erkeland S. J., Hammond S. M., Minn A. J., Rosner M. R. Raf kinase inhibitory protein suppresses a metastasis signalling cascade involving LIN28 and let-7 // EMBO J.-2009.-28, N 4.-P. 347-358.

81. Witwer K. W., SiskJ. M., Gama L., Clements J. E. MicroRNA regulation of IFN-beta protein expression: rapid and sensitive modulation of the innate immune response // J. Immunol.2010.-184, N 5.-P. 2369-2376.

82. Willner J., Wurz K., Allison K. H., Galic V., Garcia R. L., Goff B. A., Swisher E. M. Alternate molecular genetic pathways in ovarian carcinomas of common histological types // Hum. Pathol.-2007.-38, N 4.-P. 607-613.

83. Balch C., Huang T. H., Brown R., Nephew K. P. The epigenetics of ovarian cancer drug resistance and resensitization // Am. J. Obstet. Gynecol.-2004.-191, N 5.-P. 1552-1572.

84. Hara T., Noma T., Yamashiro Y., Naito K., Nakazawa A. Quantitative analysis of telomerase activity and telomerase 
reverse transcriptase expression in renal cell carcinoma // Urol. Res.-2001.-29, N 1.-P. 1-6.

85. Bantis A., Patsouris E., Gonidi M., Kavantzas N., Tsipis A., Athanassiadou A. M., Aggelonidou E., Athanassiadou P. Telomerase RNA expression and DNA ploidy as prognostic markers of prostate carcinomas // Tumori.-2009.-95, N 6.P. 744-752.

86. Schaefer A., Jung M., Mollenkopf H. J., Wagner I., Stephan C., Jentzmik F., Miller K., Lein M., Kristiansen G., Jung K. Diagnostic and prognostic implications of microRNA profiling in prostate carcinoma // Int. J. Cancer.-2010.-126, N 5.P. 1166-1176.

87. Wiley A., Katsaros D., Chen H., de la Longrais R. I. A., Beeghly A., Puopolo M., Singal R., Zhang Y., Amoako A., Zelterman $D$., $Y u H$. Aberrant promoter methylation of multiple genes in malignant ovarian tumors and in ovarian tumors with low malignant potential // Cancer.-2006.-107, N 2.-P. 299308 .

88. Chan M. W., Wei S. H., Wen P., Wang Z., Matei D. E., Liu J. C., Liyanarachchi S., Brown R., Nephew K. P., Yan P. S., Huang T. H. Hypermethylation of $18 \mathrm{~S}$ and $28 \mathrm{~S}$ ribosomal DNAs predicts progression-free survival in patients with ovarian cancer // Clin. Cancer Res.-2005.-11, N 20.-P. 7376-7383.

89. Nanjundan M., Nakayama Y., Cheng K. W., Lahad J., Liu J., Lu K., Kuo W. L., Smith-McCune K., Fishman D., Gray J. W., Mills G. B. Amplification of MDS1/EVI1 and EVI1, located in the 3q26.2 amplicon, is associated with favorable patient prognosis in ovarian cancer // Cancer Res.-2007.-67, N 7.P. 3074-3084.

90. Grady W. M. Epigenetic events in the colorectum and in colon cancer // Biochem. Soc. Trans.-2005.-33, N 4.-P. 684688 .

91. Yoon M. S., Suh D. S., Choi K. U., Sol M. Y., Shin D. H., Park W. Y., Lee J. H., Jeong S. M., Kim W. G., Shin N. R. High-hroughput DNA hypermethylation profiling in different ovarian epithelial cancer subtypes using universal bead array // Oncol. Rep.-2010.-24, N 4.-P. 917-925.
92. Farley J., Ozbun L. L., Birrer M. J. Genomic analysis of epithelial ovarian cancer // Cell Res.-2008.-18, N 5.-P. 538548 .

93. Fridman E., Dotan Z., Barshack I., David M. B., Dov A., Tabak S., Zion O., Benjamin S., Benjamin H., Kuker H., Avivi C., Rosenblatt K., Polak-Charcon S., Ramon J., Rosenfeld N., Spector $Y$. Accurate molecular classification of renal tumors using microRNA expression // J. Mol. Diagn.-2010.-12, N 5.-P. 687-696.

94. Li S. S., Sharief F. S. The prostatic acid phosphatase (ACPP) gene is localized to human chromosome 3q21-q23// Genomics.-1993.-17, N 3.-P. 765-766.

95. Zhang H. L., Yang L. F., Zhu Y., Yao X. D., Zhang S. L., Dai B., Zhu Y. P., Shen Y. J., Shi G. H., Ye D. W. Serum miRNA21: Elevated levels in patients with metastatic hormonerefractory prostate cancer and potential predictive factor for the efficacy of docetaxel-based chemotherapy // Prostate.2010.-Sep 14, doi: 10.1002/pros.21246.

96. Kahn S. L., Ronnett B. M., Gravitt P. E., Gustafson K. S. Quantitative methylation-specific PCR for the detection of aberrant DNA methylation in liquid-based Pap tests // Cancer.-2008.-114, N 1.-P. 57-64.

97. Hausler S. F., Keller A., Chandran P. A., Ziegler K., Zipp K., Heuer S., Krockenberger M., Engel J. B., Honig A., Scheffler M., Dietl J., Wischhusen J. Whole blood-derived miRNA profiles as potential new tools for ovarian cancer screening // $\mathrm{Br}$. J. Cancer.-2010.-103, N 5.-P. 693-700.

98. Skvortsova T. E., Vlassov V. V., Laktionov P. P. Binding and penetration of methylated DNA into primary and transformed human cells // Ann. N. Y. Acad. Sci.-2008.-1137.-P. 36-40.

99. Jones P. A., Martienssen R. A blueprint for a Human Epigenome Project: the AACR Human Epigenome Workshop // Cancer Res.-2005.-65, N 24.-P. 11241-11246.

UDC 577.218; 616.006.6 Received 02.11.10 